\title{
Review
}

\section{Aberrant methylation patterns in cancer: a clinical view}

\author{
Alja Videtic Paska, Petra Hudler \\ Institute of Biochemistry, Faculty of Medicine, University of Ljubljana, Ljubljana, Slovenia \\ Corresponding author: petra.hudler@mf.uni-lj.si
}

\begin{abstract}
Epigenetic mechanisms, such as DNA methylation, DNA hydroxymethylation, post-translational modifications (PTMs) of histone proteins affecting nucleosome remodelling, and regulation by small and large non-coding RNAs (ncRNAs) work in concert with cis and trans acting elements to drive appropriate gene expression. Advances in detection methods and development of dedicated platforms and methylation arrays resulted in an explosion of information on aberrantly methylated sequences linking deviations in epigenetic landscape with the initiation and progression of complex diseases. Here, we consider how DNA methylation changes in malignancies, such as breast, pancreatic, colorectal, and gastric cancer could be exploited for the purpose of developing specific diagnostic tools. DNA methylation changes can be applicable as biomarkers for detection of malignant disease in easily accessible tissues. Methylation signatures are already proving to be an important marker for determination of drug sensitivity. Even more, promoter methylation patterns of some genes, such as MGMT, SHOX2, and SEPT9, have already been translated into commercial clinical assays aiding in patient assessment as adjunct diagnostic tools. In conclusion, the changes in DNA methylation patterns in tumour cells are slowly gaining entrance into routine diagnostic tests as promising biomarkers and as potential therapeutic targets.
\end{abstract}

Key words: biomarkers; CpG islands; DNA methylation; molecular diagnostics; epigenetics

\section{Introduction}

A human genome stores the genetic information encoded as DNA sequences and all cells in multicellular organisms harbour identical genotype. The sequence arrangements contain basic information controlling and directing gene expression, which are further upgraded with different mechanisms, governing fine tuning of these processes and adding additional levels of regulation. Epigenetic modifications are one example of these mechanisms, exerting functionally relevant changes in the genome. Those modifications collectively modify gene expression patterns and control different biological processes such as cell differentiation, proliferation, pre-mRNA processing, survival, genomic imprinting, and $X$ chromosome inactivation (1-3). Epigenetic mechanisms, including DNA methylation, DNA hydroxymethylation, post-trans- lational modifications (PTMs) of histone proteins, nucleosome remodelling, and regulation by noncoding RNAs (ncRNAs) work in concert with cis and trans acting elements to drive appropriate gene expression (4-6). Cis acting elements denote DNA sequences, which are part of gene promoters or other structural portions of a coding sequence that is required for expression. Trans acting elements or factors are proteins that bind to cis acting sequences commanding gene or ncRNAs expression. In this manner, cells control DNA transcription by turning on or off coding sequences as well as non-coding functional RNAs, depending on the type of epigenetic modifications (2).

Epigenetic modifications are written, erased, read, and regulated by a set of specific proteins (1). Although many of these changes are coded within 
the genome, accumulating evidence showed that environmental influences, such as smoking, starvation, lifestyle, drugs, disease, and aging, can induce long-term changes in epigenetic memory (13). It appears that these changes could also be heritable as well as sustained and transmitted through several generations $(3,7,8)$. Hence, the dynamic epigenetic landscape is a bridge between environmental exposures and more stable genetic information, stored in the genome, allowing multicellular organisms' quick adaptation mode, thus abrogating the necessity for time-consuming process of changing the DNA sequence through mutations followed by natural selection $(2,7)$.

Dysregulation of epigenetic memory has been attributed as pathogenic mechanism driving the initiation and progression of several complex diseases. A vast amount of research has been performed linking aberrant DNA methylation profiles and histone modifications to developmental defects, obesity, asthma, cancers and neurodegenerative diseases (9). However, given the complexity of epigenetic mechanisms, which are further influenced by aging, human genetic variations, such as polymorphisms, and environmental factors, there is still a long way towards collecting, researching, and deciphering of epigenetic information $(7,10)$. Translation of all these mechanisms into relevant biological information will require combined efforts of scientists from different fields.

In this review we attempted to give the medical readers an overview of the epigenetic field by discussing DNA methylation in the context of its dysregulation in selected epithelial cancers. More specifically, we discussed potential significant aberrant methylation patterns in breast, pancreatic, colorectal, and gastric cancer. These cancer types represent informative cancer models where heterogeneous epigenetic nature hampers the search for specific and sensitive biomarkers; although enormous research efforts had already produced successful diagnostic aids for some of them. We focused on DNA methylation markers, which could be most relevant for translation into clinical setting and could be detected in easily accessible diagnostic specimens.

\section{DNA methylation}

Feinberg and Vogelstein were the first to associate differences in DNA methylation status to cancer in the early $80^{\prime}$ of the previous century (11). Since then, there has been an explosion of research regarding aberrant DNA methylation in complex diseases (Figure 1). Simplicity of techniques employed for DNA methylation research and recently developed genome-scale methods for mapping DNA methylation across whole genomes have already resulted in translation of basic discoveries. Therefore, aberrant methylation of genes were associated with diseases, such as colorectal cancer, PraderWilli, Angelman, Beckwith-Wiedmann syndromes and introduced into routine clinical diagnostics. DNA methylation patterns work in close association with histone modifications and chromatin structure, building transcriptionally active or repressed chromatin $(2,7,12)$. It is important to recognize that crosstalk between these three mechanisms is complex and that aberrant DNA methylation can impact histone modifications and chromatin structure. The opposite mechanism is also possible, so histone modifications and dysregulation of histone modifying proteins can also influence DNA methylation patterns.

\section{Mechanisms of DNA methylation}

In mammalian cells, DNA methylation consists of covalent attachment of a methyl group to the $5^{\prime}$ position of cytosine residues in CG dinucleotides $(2,3)$. CG dinucleotides are not randomly distributed throughout the genome, but tend to cluster in regions called $\mathrm{CpG}$ islands, mainly present in the gene promoters $(2,5,6)$. An accepted definition of CpG islands describes them as DNA sequences, more than 200 base pairs long, with CG content greater than $50 \%$ and an observed / expected CpG ratio of more than $60 \%(5,13)$. Methylation can also occur at non-promoter CpG islands, defined as CpG shores, located in the vicinity of $\mathrm{CpG}$ islands up to 2 kilobases long $(5,14,15)$. Methylation of CpG islands is typically associated with gene silencing, while demethylation of these sites enables transcription $(1,5)$. Methylation physically prevents the binding of regulatory proteins, which promote 


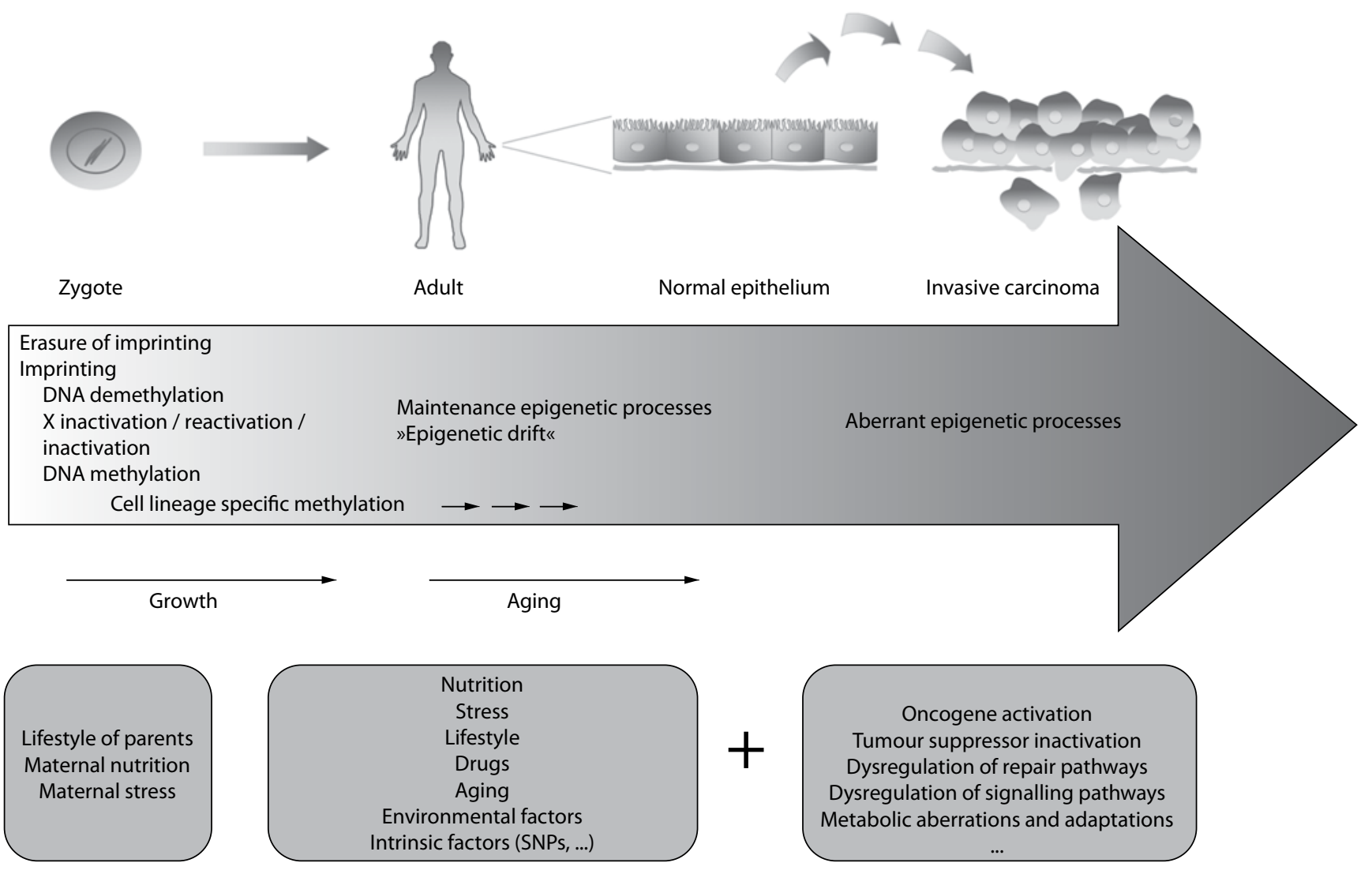

Figure 1. DNA methylation and complex diseases.

transcription, and through binding of methylation-sensitive proteins, which mask regulatory sequences or by interacting with histone modifications that modulate the structure of chromatin, enabling or disabling access of transcriptional machinery to promoters $(1,3)$. All these epigenetic marks work together to compress nucleosomes into transcriptionally unfavourable conformation, heterochromatin (3).

Methylation patterns in differentiated cells are mostly stable and inheritable (13). However, specific proteins, DNA methyl-transferases (DNMTs), can establish novel methylation marks in response to environmental triggers (3). DNMT3a and DNMT3b are responsible for the de novo methylation, while DNMT1 maintains silencing inheritance patterns through mitosis $(1,3)$. Some DNMTs remain tightly associated with nucleosomes; their binding assisted through interactions with methyl binding domains (MBDs), and may recruit other proteins containing MBDs to reinforce the silencing. These complexes further interact and recruit proteins involved in histone modifications (3).

Demethylation process is mainly active in early embryo development and can occur via passive demethylation during cell division or via active demethylation using TET1 and TET2 mediated hydroxylation of 5-methylcytosine to 5-hydroxymethylcytosine, followed by deamination and base excision repair (1).

\section{Methods for DNA methylation discovery}

DNA methylation represents a new opportunity in cancer genetics to provide biomarkers for diagnostic and prognostic use in clinical environment (16). In the past decade, due to significant technical developments, the research of DNA methylation has evolved from locus specific approach to genome-wide determination of methylome with base pair resolution (17). 
Many different techniques for DNA methylation determination exist, and choosing the most appropriate one largely depends on the nature and number of the samples, information required, and costs. The three main approaches are: methylation-specific restriction enzyme digestion, affinity purification of methylated DNA and bisulfite conversion of DNA (18). The DNA obtained is further subjected to molecular-genetic approaches, which are for single locus analysis based on PCR, whereas in the case of genome-wide interrogation they are based either on microarray technology, mass spectroscopy or next generation sequencing analysis.
In the beginning the DNA methylation studies were performed with methylation-sensitive restriction enzymes and Southern blotting (19). However, today the majority of the methods rely on bisulfite conversion of DNA and subsequent PCR-based method (Table 1). The application of bisulfite treatment demands laboratory experience, since it can lead to DNA degradation and unwanted conversion of methylated cytosines to thymines when the incubation times are prolonged or incomplete conversion if incubation is too short. In order to overcome these problems numerous commercially available kits for bisulfite conversion

TABLE 1. Commonly used techniques for locus specific DNA methylation determination based on bisulfite sequencing with potential for translation into clinical practice.

\begin{tabular}{|c|c|c|}
\hline Method & Advantages & Disadvantages \\
\hline $\begin{array}{l}\text { Methylation specific } \\
\text { PCR } \\
\text { (MSP-PCR) }\end{array}$ & $\begin{array}{l}\text { Very sensitive. } \\
\text { Cost-effective. }\end{array}$ & $\begin{array}{l}\text { Need for two different pairs of primers, one for } \\
\text { methylated DNA and one for non-methylated. } \\
\text { Risk for false positive results if primer design is not } \\
\text { appropriate. } \\
\text { Only qualitative. }\end{array}$ \\
\hline SMART-MSP & $\begin{array}{l}\text { Low rate of false positive results. } \\
\text { High sensitivity. } \\
\text { Closed tube technique - low risk for sample } \\
\text { contamination. }\end{array}$ & $\begin{array}{l}\text { Determination of methylated DNA only. } \\
\text { Not suitable for detection of heterogeneous } \\
\text { methylation. }\end{array}$ \\
\hline MethyLight & $\begin{array}{l}\text { Very high analytical sensitivity. } \\
\text { Low false positive rates. } \\
\text { Closed tube technique - low risk for sample } \\
\text { contamination. }\end{array}$ & $\begin{array}{l}\text { Only for detection of methylated DNA. } \\
\text { When samples with heterogeneous DNA } \\
\text { methylation are analysed it is only semi-quantitative }\end{array}$ \\
\hline $\begin{array}{l}\text { Methylation-sensitive } \\
\text { high resolution } \\
\text { melting (MS-HRM) }\end{array}$ & $\begin{array}{l}\text { Useful for screening purposes - high throughput, } \\
\text { inexpensive, fast. } \\
\text { Real - time tracking of methylation status. } \\
\text { Applicable also for small amounts of DNA. } \\
\text { Closed tube technique - low risk for sample } \\
\text { contamination. }\end{array}$ & $\begin{array}{l}\text { Information on methylation degree based on } \\
\text { standard curve analysis - semi-quantitative. } \\
\text { No information on specific sites of methylation - } \\
\text { patterns are hard to recognize. }\end{array}$ \\
\hline $\begin{array}{l}\text { Sanger sequencing of } \\
\text { bisulfite treated DNA }\end{array}$ & $\begin{array}{l}\text { Data on complete sequence composition. } \\
\text { Relatively long sequence reads possible. }\end{array}$ & $\begin{array}{l}\text { Only semi - quantitative. } \\
\text { Low quality results at the beginning of the reads. }\end{array}$ \\
\hline Pyrosequencing & $\begin{array}{l}\text { Quantitative analysis of individual CpG islands with } \\
\text { real - time monitoring. } \\
\text { Appropriate for degraded formalin-fixed, paraffin - } \\
\text { embedded (FFPE) samples. }\end{array}$ & $\begin{array}{l}\text { Relatively short sequences ( } ~ 50 \text { nucleotides) can be } \\
\text { reliably analysed. }\end{array}$ \\
\hline $\begin{array}{l}\text { Next generation } \\
\text { sequencing }\end{array}$ & $\begin{array}{l}\text { High throughput. } \\
\text { Data on complete sequence reads - genetic and } \\
\text { epigenetic data. } \\
\text { Quantitative. }\end{array}$ & $\begin{array}{l}\text { Need for high-quality DNA. } \\
\text { Relatively labour demanding. } \\
\text { Still associated with high costs. } \\
\text { Currently used / applicable for research use only. } \\
\text { Purchase of an expensive instrument is required. }\end{array}$ \\
\hline MassARRAY EpiTYPER & $\begin{array}{l}\text { Quantitative analysis, high throughput, applicable } \\
\text { for heterogeneous DNA methylation patterns. }\end{array}$ & Investment into expensive instruments is required. \\
\hline
\end{tabular}


of DNA isolated from different sample types were developed (20).

When performing the analysis of the specific locus, the investigated region should ideally be unmethylated in normal tissue and methylated in cancerous tissue or vice versa. In addition, the methylation levels should enable differentiation between the two statuses of the samples (21).

In the laboratory setting one of the mostly used methods for locus specific methylation biomarkers is pyrosequencing, which is very appropriate for degraded formalin-fixed, paraffin-embedded (FFPE) samples that are an important part of tissue bio-banks. The technique enables quantitative analysis of each CpG position (22). Another method, which is fast and also robust, is high resolution melting (HRM) curve analysis. Two typical methods in wider use are methylation-sensitive HRM (MS-HRM) curve analysis and quantitative real time PCR, such as SMART-MSP (23). Both techniques are relatively cheap and sensitive, allow relatively good throughput and quantification, and are closed tubes techniques. The latter minimizes the risk for sample confusion and cross-contamination which is of vital importance in clinical laboratory $(16,24)$. The MS-HRM method has already been tested on samples with small amounts of DNA, like stool, and has proven to be sensitive and reliable enough to be used for screening purposes (25). Both techniques have demonstrated to be successful also on old FFPE tissues (26). However, these techniques require well designed primer pairs and stringent annealing temperatures in order to overcome the problem with false positive results. They are also not completely reliable when analysing heterogeneous DNA methylation patterns.

Another useful technique, still considered as a single locus analysis, is the matrix-assisted laser desorption ionization - time of flight (MALDI-TOF). The Sequenom Inc. has developed a sensitive and high throughput assay MassARRAY ${ }^{\circledR}$ EpiTYPER $^{\circledR}$, which enables quantitative screening and differential methylation analysis in cancer samples (27).

Roche 454 Genome Sequencer and Illumina Genome analyser are the most used next generation sequencing platforms in research (28) and therefore likely to be validated for clinical use. They are becoming the key players in cancer genome-wide methylome determination, which could result in determination of an array of biomarkers. These arrays should subsequently be subjected to thorough testing on larger sample cohorts using more-cost effective methods. The costs of nextgeneration sequencing are currently still too high to allow larger sample testing. So far research performed on these platforms proves to be useful to provide fingerprints of cancer methylomes, which could help in cancer subtypes classification. However, due to the limited knowledge of functional consequences of methylation aberrations, enormous number of discovered changes and overlapping changes between different cancers, establishment of cancer specific methylation signatures is still far away.

Roche 454 system was one of the first platforms that enabled a comprehensive multi-sample, multi-gene, and ultra-deep sequencing of cancer DNA generating specific methylation patterns. Beside the high number of reads, and therefore detailed sequence coverage, an important advantage of this technology was simultaneous exploration of genetic and epigenetic data (29). Another platform that offers genome-wide methylome studies is the Infinium HumanMethylation BeadChip microarray platform (Illumina). One of the most useful arrays seems to be the one with 27,578 highly informative $\mathrm{CpG}$ islands located within the proximal promoter regions (30). However, this technology needs high-quality DNA, which is not the most optimal for clinical setting, since the samples are mostly stored as FFPE. The comparison of fresh-frozen samples with FFPE showed that the correlation of results between them was not optimal (31).

As we have seen, the methods for DNA methylation analysis are abundant, however, when considering their application for use in clinical diagnostics the main drawbacks are the standardization of methods between laboratories, determination of reference standards, and costs, associated with training of personnel and obtaining new equipment (16). DNA methylation techniques that could 
be used in clinical setting should be easy to use, high throughput, preferably automatable, applicable on degraded DNA, cost-effective, and should provide quantitative methylation data $(16,21)$. On the other hand, DNA methylation is a stable covalent modification, present at single or multiple CpG sites, and as such may be easily translated into robust and high performance laboratory tests (32). Furthermore, biomarker evaluation should be performed in readily accessible diagnostic specimens, such as blood, urine, faeces or saliva in order to detect early stages of the disease.

\section{Methylation profiles of selected cancer types - current knowledge}

DNA methylation biomarkers could be used in two different ways: as confirmatory diagnostic, prognostic and predictive markers in an already diagnosed tumour or as markers for early disease and/ or residual disease screening $(21,33)$.

An important feature of cancers is global hypomethylation across the genome, whereas hypermethylation is mostly observed locally (21). It is assumed that the consequence of hypomethylation of single-copy genes is activation of expression, leading to enhanced oncogenic potential. The role of hypomethylation of repeated sequences, which comprise $45 \%$ of human genome, is less understood, although it has been hypothesized to facilitate genomic instability (34). Hypermethylation, on the other hand is associated with inactivation of tumour suppressor genes and genes, implicated in normal homeostasis of tissues (35).

When the methylation status of whole genome is determined it is referred to as a cancer methylome fingerprint, while designation of methylation biomarker applies to methylation status of particular sites in the genome. Both are important in the development of clinical protocol that could enable the clinician to better diagnose and stage the disease, and to predict the prognosis and monitor the response to therapy (36).

The number of studies analysing the methylome and focal hypermethylation is enormous. However, so far there are only a few CE-IVD approved
DNA methylation biomarkers, like MGMT in gliomas (37) or SEPT9 for colorectal cancer and SHOX2 for lung cancer in clinical use. This is mainly due to big inter-study differences, which makes it hard to compare the results in an unambiguous way. This has been clearly demonstrated by Li and co-workers who performed meta-analysis to evaluate the prognostic value of global DNA hypomethylation in cancer (38). Their initial search retrieved $146 \mathrm{ci}-$ tations, but after checking them for a few criteria, like assessment of global DNA hypomethylation level, the survival, the hazard ratio, and the sample size of more than thirty subjects, only 20 studies remained eligible to be included in the meta-analysis (38). Although the initial differences were pronounced, the pooled analysis of all the included studies demonstrated that global DNA hypomethylation could be associated with worse survival in cancer patients (38).

Studies showed that it is challenging to find biomarkers with high informativeness for clinical use, despite the fact that some results seem to replicate across studies. However, more defined protocols for study executions and more consensuses regarding the methods used should be established to gain applicable knowledge in the near future.

\section{Breast cancer}

Genome-wide expression analyses have defined five biologically and clinically distinct cancer subtypes of breast cancer: luminal-A, luminal-B, HER2, normal-like, and basal-like (39). Timely detection of breast cancer is crucial for better prognosis and treatment, since the survival drops from $98 \%$ to $20 \%$ when tumour metastases appear (40). Among the first findings in breast cancer genetics were BRCA1 mutations, which importantly elevate the risk for the disease. Furthermore, it has been shown that not only genetic mutations, but also promoter methylation patterns represent a marker, particularly for early detection of malignant growth. Namely, Wong and co-workers determined that BRCA1 promoter methylation was associated with 3.5-fold increased risk for early onset of breast cancer. Importantly, they used peripheral 
blood as diagnostic specimen for the determination of methylation status of BRCA1 promoter, which could be therefore used as a screening tool (41). Promoter hypermethylation of BRCA1 could serve also as predictive biomarker for PARP1 inhibitor therapy, which has been currently used only for treatment of patients with BRCA1 and BRCA2 mutations to decrease the growth and vascularisation of tumour (42).

Since breast cancer has many faces, so far no gene that would apply to all the subtypes has been determined. Studies, analysing smaller panels of genes seem to be the most promising way towards a clinically relevant assay for breast cancer diagnostics. In the following section we will review the most recent studies of assays with clinical relevance.

The most recent study on advanced breast cancer, which could be used in monitoring and treatment response, was performed by Fackler and co-workers who tested a panel of 10 markers on cell-free circulating DNA (cfDNA) (43). The proposed assay was based on their previous results from Infinium Human Methylation27K Beadchip on tumour and serum samples from patients, and on normal samples of breast tissue and serum. The markers included in the test had low methylation levels in normal samples and high levels in cancer ones. The selected markers were AKR2B2, COL6A2, GPX7, HIST1H3C, HOXB4, RASGRF2, and TM6SF1, and additionally three markers, ARHGEF7, TMEFF2, and RASSF1A, previously associated with breast cancer, were chosen. The specificity and sensitivity of the assay were $96.4 \%$ and $91.7 \%$, respectively. The best individual performance was obtained for the genes RASSF1A, HIDR1H3C, RASGRF2, COL6A2, $H O X B 4$, and $A K R 1 B 1$, which combined in a panel, performed almost as good as the 10 - gene panel (Table 2). Furthermore, the results showed applica-

TABLE 2. Selected candidate DNA methylation markers in breast, colorectal, gastric and pancreatic cancers.

\begin{tabular}{|c|c|c|c|}
\hline Cancer type & DNA methylation marker & Main results & Reference \\
\hline \multirow[t]{6}{*}{ Breast } & $\begin{array}{l}\text { RASSF1A, HIDR1H3C, } \\
\text { RASGRF2, COL6A2, HOXB4, } \\
\text { AKR1B1 }\end{array}$ & $\begin{array}{l}\text { High methylation levels in cancer samples. } \\
\text { Applicable for measuring treatment response. }\end{array}$ & $(43)$ \\
\hline & DKK3, ITIH5, RASSF1A & $\begin{array}{l}\text { Possible to discriminate breast cancer patients from benign cases and } \\
\text { healthy controls with sensitivity of } 51.4 \% \text { and a specificity of } 80.5 \% \text {. }\end{array}$ & $(44)$ \\
\hline & DKK3, ITIH5 & $\begin{array}{l}\text { Candidate genes for early cancer detection with } 52 \% \text { and } 100 \% \\
\text { sensitivity and specificity, respectively. }\end{array}$ & $(44)$ \\
\hline & $\begin{array}{l}\text { APC, BIN1, BRCA1, CST6, } \\
\text { GSTP1, P16, P21, TIMP3 }\end{array}$ & $\begin{array}{l}\text { Higher methylation of cfDNA in cancer patients compared to controls } \\
\text { with over } 90 \% \text { for either plasma or serum samples or both. Results } \\
\text { were confirmed also on triple matched samples from tumour, normal } \\
\text { and serum sample. }\end{array}$ & $(45,46)$ \\
\hline & $M A L$, RASSF1A, SFRP1 & $\begin{array}{l}69 \% \text { specificity and } 100 \% \text { sensitivity of the test was achieved } \\
\text { when using the combination of cfDNA ALU247 quantification and } \\
\text { methylation status. }\end{array}$ & $(47)$ \\
\hline & $\begin{array}{l}\text { BCAP31, FZD9, HDAC1, } \\
\text { HOXA11, LYN, PTPRH, } \\
\text { ST6GAL1, TFF1 }\end{array}$ & $\begin{array}{l}\text { Strong associations between methylation and ER status, } \\
\text { PR status, TP53 mutation status, histological grade and molecular } \\
\text { subtype. } \\
\text { BCAP31 hypomethylation showed worse survival and OGG1 } \\
\text { hypermethylation showed that patients with normal - like levels of } \\
\text { methylation. }\end{array}$ & $(48)$ \\
\hline \multirow[t]{3}{*}{ Pancreatic } & Test of $1505 \mathrm{CpG}$ sites & $\begin{array}{l}\text { Blood-based test. With a model with five CpG sites (IL10_P348, } \\
\text { LCN2_P86, ZAP70_P220, AIM2_P624, TAL1_P817) could differentiate } \\
\text { between patients and controls. }\end{array}$ & $(58)$ \\
\hline & ADAMTS1, BNC1 & Early stage cancer diagnostics. & $(55)$ \\
\hline & & Could be used as a screening tool for high-risk individuals. & \\
\hline
\end{tabular}


TABLE 2. Continued.

\begin{tabular}{|c|c|c|c|}
\hline Cancer type & DNA methylation marker & Main results & Reference \\
\hline & NPTX2 & $\begin{array}{l}\text { Potential biomarker for differential diagnostics of pancreatic cancer } \\
\text { and chronic pancreatitis, and early disease detection with sensitivity } \\
\text { and specificity of } 80 \% \text { and } 76 \% \text {, respectively. }\end{array}$ & $(56,57)$ \\
\hline & ACIN1, TNFRSF10C & $\begin{array}{l}\text { Blood-based test. Hypermethylation of TNFRSF10C and ACIN1 } \\
\text { associated with shorter survival. } \\
\text { Higher levels of TNFRSF10C methylation were associated with } \\
\text { perineural spread of cancer cells. }\end{array}$ & $(59)$ \\
\hline \multirow[t]{9}{*}{ Colorectal } & $\begin{array}{l}\text { Genome-wide differential } \\
\text { methylation patterns }\end{array}$ & $\begin{array}{l}\text { Identification of differential methylation patterns that could be used } \\
\text { for distinguishing cancer tissues from normal ones. }\end{array}$ & $(15,61,65-67)$ \\
\hline & $M G M T$ & $\begin{array}{l}\text { MGMT hypermethylation detection in blood or tissues is used as an } \\
\text { aid in diagnostic detection of CRC cells, clinical research, and pharma/ } \\
\text { biopharma testing. }\end{array}$ & $(71-73)$ \\
\hline & SEPT9 & $\begin{array}{l}\text { SEPT9 hypermethylation detection in blood plasma is used as an aid } \\
\text { in diagnostic evaluation of CRC. }\end{array}$ & $(74,76,79-81)$ \\
\hline & VIM & $\begin{array}{l}\text { Vimentin hypermethylation detection in stool samples (and blood) is } \\
\text { used as an aid in diagnostic detection of CRC cells. }\end{array}$ & $(77,78)$ \\
\hline & ALX4, SEPT9, TMEFF2 & $\begin{array}{l}\text { The sensitivities and specificities of the combined biomarkers for the } \\
\text { detection of CRC in primary tissues and peripheral blood samples } \\
\text { were } 84 \% \text { and } 81 \% \text { and } 87 \% \text { and } 90 \% \text {, respectively. }\end{array}$ & (74) \\
\hline & $\begin{array}{l}\text { SOX21, SLC6A15, NPY, GRASP, } \\
\text { ST8SIA1, ZSCAN18) }\end{array}$ & $\begin{array}{l}\text { Hypermethylation of these genes was detected in at least } 50 \% \text { of } \\
\text { CRC tissues and low levels of methylation in non-neoplastic colorectal } \\
\text { tissues showing a potential to be developed into stool-based assays. }\end{array}$ & $(61)$ \\
\hline & $\begin{array}{l}\text { BCAT1, COL4A2, DLX5, FGF5, } \\
\text { FOXF1, FOXI2, GRASP, IKZF1, } \\
\text { IRF4, SDC2, SOX21 }\end{array}$ & $\begin{array}{l}\text { Hypermethylation of these genes was detected in CRC tissue and low } \\
\text { methylation levels were characterized in blood samples from healthy } \\
\text { subjects rendering them suitable for evaluation as blood-based CRC } \\
\text { biomarkers. }\end{array}$ & $(61)$ \\
\hline & $\begin{array}{l}\text { BMP3, CACNA1G, CDKNA2, } \\
\text { CDH1, COrf50, IGF2, NEUROG1, } \\
\text { MGMT, MLH1, RUNX3, SFRP2, } \\
\text { SOCS1, THBD, VHL }\end{array}$ & $\begin{array}{l}\text { Additional candidate biomarkers for detection of CRC cells that are } \\
\text { often hypermethylated in malignant cells }\end{array}$ & $\begin{array}{l}(12,61,62 \\
71-78,80,81)\end{array}$ \\
\hline & IGF2, LINE-1 & $\begin{array}{l}\text { Candidate biomarkers for CRC showing frequent hypomethylation } \\
\text { in pre-malignant lesions, possibly suitable for early detection of CRC. } \\
\text { May play role in progression of distinct subtypes of CRC. }\end{array}$ & $(63,64)$ \\
\hline \multirow[t]{4}{*}{ Gastric } & $\begin{array}{l}\text { Genome-wide differential } \\
\text { methylation patterns }\end{array}$ & Variable hypermethylation and hypomethylation landscape. & $(93,94)$ \\
\hline & CRK, MOS & $\begin{array}{l}\text { Hypermethylated in tissues from patients positive for Helicobacter } \\
\text { pylori infection and hypomethylated in tissues from patients with } \\
\text { advanced gastric cancer. May be suitable for development of } \\
\text { methylation assays for patients with } H \text {. pylori infection showing no } \\
\text { pre-malignant lesions. }\end{array}$ & (99) \\
\hline & $\begin{array}{l}\text { ADAM23, APC, BMP-2, } \\
\text { BX161496, CACNA2D3, CDH1, } \\
\text { CDX2, CHFR, CHRNA3, DAPK, } \\
\text { DCC, DOK1, GDNF, GNMT, } \\
\text { HOXA5, ITGA4, ITGAM, KCNA4, } \\
\text { MGMT, MINT25, MLF1, MLH1, } \\
\text { P16, p14ARF, PRDM5, RASSF1A, } \\
\text { RELN, RPRM, RUNX3, SOCS1, } \\
\text { SULF1, TFPI, TIMP3, TRIM15, } \\
\text { VAV1, WNT5A, WT1, ZIC1 }\end{array}$ & $\begin{array}{l}\text { Candidate genes showing frequent hypermethylation in gastric } \\
\text { cancer tissues. }\end{array}$ & $(92,93,95-99)$ \\
\hline & $\begin{array}{l}\text { ALDH2, FAM38A, LINE-1, } \\
\text { MSX2, MTHFR, PTPN6, STAT5A }\end{array}$ & $\begin{array}{l}\text { Candidate genes showing frequent hypomethylation in gastric cancer } \\
\text { tissues. }\end{array}$ & $(92,93,99)$ \\
\hline
\end{tabular}

cfDNA - cell-free circulating DNA, CRC - colorectal cancer. 
bility for measuring the treatment response, which could be of great benefit for physician (43). Kloten and co-workers studied promoter methylation of seven genes SFRP1, SFRP2, SFRP5, WIF1, DKK3, ITIH5, and RASSF1A. They performed the analysis on test set of samples, and did the validation of the best markers DKK3, ITIH5, and RASSFIA on additional independent samples. They were able to achieve sensitivity of $51.4 \%$ and a specificity of $80.5 \%$ to distinguish breast cancer patients from both healthy and benign controls. The sensitivity and specificity of DKK3 and ITIH5 in premenopausal women was $52 \%$ and $100 \%$, respectively, making them promising candidates for early cancer detection (44). Radpour and co-workers tested different set of ten tumour suppressor genes (APC, BIN1, BMP6, BRCA1, CST6, ESR-b, GSTP1, P16, P21 and TIMP3) for which they determined in their previous study to be hypermethylated in breast cancer tumours compared to controls (45). Eight of the studied genes showed the methylation level statistically significantly higher in cfDNA of patients compared to controls. The panel of these eight genes reached the specificity of $91.7 \%$ for plasma samples, and $95 \%$ for serum samples, and more than $90 \%$ specificity for both specimens. The higher methylation of cfDNA for seven genes was associated with higher methylation in solid tumours, compared to normal control tissues, which proves the cancerous tissue as the source of the cfDNA (46). Another study on cfDNA that was associated with early diagnosis of breast cancer was performed by Agostini and co-workers, who determined that amount of cfDNA and methylation of RASSF1A, MAL, and SFRP1, could be used as predictive biomarker (47).

Fleischer and co-workers performed an integrated analysis, where they tested blood sample methylation status of 27 gene promoters which were further associated with gene expression, germline genotypes, and clinical parameters. They determined that methylation was more strongly associated with clinical parameters than gene expression, supporting the idea of methylation being a robust biomarker. On individual level, the methylations of BCAP31 and OGG1 were associated with survival and better prognosis, if the methylation levels of those two genes were similar to levels in normal controls (48).

As seen in the latest studies of biomarker panels, the results still highly depend on the study design, where majority of the proposed assays stem from previous whole-genome results of research groups proposing the 'new' potential tests. Therefore, majority of the genes studied are diverse between the studies, and thorough validation studies are needed to achieve the desired sensitivity and specificity.

\section{Pancreatic cancer}

So far, the gold standard for pancreatic cancer serum biomarker in clinical practice has been the carbohydrate antigen (CA) 19-9 (49). Recent metaanalysis has shown that it has the sensitivity and specificity of 0.8 , which places it as an important diagnostic biomarker in clinical environment (50). However, it is not applicable for early-stage cancer diagnostic. As the patients with developing pancreatic cancer do not have clear clinical manifestations, early stages of the disease are difficult to diagnose, resulting in poor prognosis and high mortality (49). The search for new biomarkers that could be used for screening and prognostic purposes has been lately oriented towards epigenetics as aberrant DNA methylation has been observed already during the earliest stages of disease development (51).

Excellent recent review papers have compiled extensive data on aberrantly methylated genes in pancreatic cancer (49,51-53). The other valuable source of information is Pancreatic Cancer Methylation Database which covers the five major subtypes of pancreatic cancer and has currently over 65,000 entries on methylation status of more than 4000 genes (54).

DNA methylation biomarkers that could indicate the existence of the precursor lesions are of great importance, since well-timed detection is one of the key issues in pancreatic cancer diagnosis. Yi and co-workers focused on two genes for earlystage cancer detection, BNC1 and ADAMTS1 that were detected as aberrantly methylated using ge- 
nome-wide study. With the methylation analysis of these two genes on FFPE and serum samples they were able to detect early-stage cancers at a much higher frequency than with the current biomarker CA19-9. The use of these two genes for screening high-risk individuals in populations (e.g. the ones with family history of pancreatic cancer, hereditary pancreatitis, familial non-polyposis colorectal cancer or mutations in $B R C A 1 / 2$ ) could therefore be justifiable (55). A study using cfDNA from plasma of patients with pancreatic cancer, chronic pancreatitis and benign biliary stone disease showed that the methylation level of NPTX2 promoter, which has been previously detected as aberrantly methylated in pancreatic cancer tissue, was significantly higher in cancer patients compared to the other two tested groups $(56,57)$. The sensitivity and specificity were $80 \%$ and $76 \%$, respectively, making the NPTX2 a good potential biomarker for differential diagnostics and early disease detection (57).

In two other studies the DNA for methylation analysis was extracted from whole blood. Pedersen and co-workers performed a rather large study in two phases. Out of 1,505 CpG sites in phase I, 88 were selected and tested in phase II. They were able to differentiate between pancreatic adenocarcinoma and control samples; however, no relation of the obtained biomarkers with disease staging or other clinical parameters was available (58). Dauksa and co-workers designed a more clinically oriented study, although on a smaller sample and on promoter regions of nine tumour suppressor genes. They showed that hypermethylation of TNFRSF10C and ACIN1 was associated with shorter survival, and that higher levels of TNFRSF10C methylation were associated with perineural spread of cancer cells (59).

The so far determined biomarkers need further validation, but they have the potential to become clinically useful for early and differential diagnostics.

\section{Colorectal cancer}

Despite enormous efforts invested in the search for biomarkers that would allow early diagnosis, colorectal cancer (CRC) still remains the second leading cause of cancer-related deaths. Although hereditary types of CRC have been well characterized and main pathobiological mechanisms implicated in the onset of the disease have been revealed, the underlying causes for a large proportion of sporadically occurring CRC and a smaller subset of CRC with hereditary origins remain elusive $(12,60)$.

Several decades of epigenetic research have shown that aberrant DNA methylation is characteristic for sporadic CRC and that it is probably predominantly involved in the early events during malignant phenotype progression $(12,34,61)$. These changes involve global hypomethylation events as well as focal hypermethylation of CpG islands and shores in the promoter regions of specific genes $(12,15,34,61,62)$.

Initially, several well-designed studies have identified loss of methylation in CpG islands located in repetitive sequences of DNA, such as LINE-1 and Alu $(63,64)$. These discoveries were subsequently followed by novel findings supported with the advances in methods, capable of interrogating whole-genome methylation status. Several groups demonstrated hypomethylation of approximately one-third of genes, which were normally hypermethylated in normal colorectal tissues, and hypomethylation of long blocks of DNA, which were in normal cells packed within transcriptionally inactive heterochromatin $(15,34,65)$. These long blocks were mostly associated with regions that corresponded to large organized chromatin lysine modifications (LOCKs), enriched in histone modifications characteristic for heterochromatin, or portions of chromatin associated with nuclear lamina, lamina-associated domains (LADs) $(15,34,65-67)$. It is important to note, that the main feature of all these findings is extreme hypervariability in the methylation patterns and it seems that not only changes in gene expression and increased genome instability through enhanced recombination events and double strand breaks but also general variability of hypomethylation landscape is equally important in driving the neoplastic transformation (34).

In parallel with hypomethylation research, a great effort has been invested in discovering and eluci- 
dation of hypermethylation patterns in CRC. Hypermethylation of $\mathrm{MLH} 1$ remains one the few biomarkers that were translated into clinical utility for distinguishing sporadic CRC from hereditary Lynch syndrome, which is mostly characterized by mutations in mismatch repair genes, particularly $M L H 1$, $M S H 2$, and MSH6, and EPCAM. However, hundreds of mutations have been discovered in these genes, and for many of those, the pathogenicity and their functional effect on the protein product is still difficult to interpret, indicating that other pathogenic mechanisms, including epigenetic, might underlie the tumorigenesis (68-70).

MGMT hypermethylation is novel hypermethylated biomarker used in clinical diagnostics, associated with distinct mutator pathway, leading to CRC (71-73). Interestingly, it was demonstrated that polymorphism rs16906252 is closely associated with the onset of MGMT hypermethylation, thus confirming the complex nature and crosstalk between cis-acting DNA sequence and epigenetic modifications (72).

Many laboratories further identified panels of genes methylated with high frequency in CRC, such as ALX4, BMP3, CACNA1G, CDKNA2,CDH1, Corf50, IGF2, NEUROG1, RUNX3, SEPT9, SFRP2, SOCS1, THBD, TMEFF2, VHL, and VIM $(12,61,62,74,75)$. Notably, selected panels of methylated biomarkers have been interrogated using blood specimens from patients, reaching over $80 \%$ sensitivities and specificities $(62,74)$. Despite extensive confirmation and validation of these epimarkers in large cohorts of patients, their clinical utility has not been reliably confirmed. However, first generations of commercially available methylation test assays, such as Epi proColon Assay (Epigenomics AG), ColoVantage ${ }^{\circledR}$ (Quest Diagnostics) and Abbott RealTime mS9 (Abbott Laboratories) for detecting mSEPT9 and ColoSure ${ }^{\mathrm{TM}}$ (LabCorp) for detecting mVIM have been validated as pre-screening biomarkers in asymptotic individuals with varying results (76-81).

In conclusion, epigenetic modifications seem to play an important role in CRC tumorigenesis; however, screening for specific methylation changes in genes is not yet justified. Deciphering the func- tional impact of aberrant CpG island methylation in the complex context of all the intrinsic and environmental factors, which influence epigenome, will require further studies and integration of genomic, epigenomic and proteomic data. More important, as Timp and Feinberg suggested in their recent review, research showed that farreaching goal might be detecting the departure of methylation signatures from normal ones using expensive whole-genome technologies (34).

\section{Gastric cancer}

After decades of research it is clear that gastric cancer is a multifactorial disease involving environmental factors, such as Helicobacter pylori and Epstein-Barr virus infection, obesity, salt intake, tobacco use, alcohol consumption, and genetic susceptibility $(35,82-85)$. H. pylori has been recognized as class I pathogen affecting the methylation status of $C D H 1$ and several other genes, transposable elements, and repetitive DNA sequences $(83,86-$ 90). In some instances it seems that persistent $H$. pylori infection might influence specific hypermethylation of some genes, which could be eventually used as diagnostic biomarkers; however, the universal biomarkers have not yet been clearly identified. Interestingly, it has also been demonstrated that physical activity and nutrition could significantly affect methylation status of genes (91). The overall picture is further complicated by the different ethnical backgrounds of the subjects and the fact that methylation is dynamic and greatly affected by lifestyle, nutrition, drugs and chemotherapy.

Methylation events are much less characterized in gastric adenocarcinomas compared to CRC. Several studies have shown that, in general, gastric cancer cells and cancer-associated stroma exhibit global hypomethylation of genomic DNA and focal hypermethylation of several transcription sites (92-95). More than 500 publications have reported on the presence of specific promoter hypermethylation in gastric cancer (96). Due to limited space, it is impossible to present all relevant findings; however, interested readers are referred to excellent reviews, compiling relevant methylation 
changes in association with gastric cancer for further information $(9,89,97)$.

Furthermore, meta-analyses of methylation patterns in gastric cancer tissues highlight the controversy of CpG island methylator phenotype (CIMP) in this type of cancer $(38,96,98)$. Next to large variability in assays, sample collection, sample storage, and examined gene panels, many issues relevant to clinical implementation remain unaddressed (96). Likewise, lack of validation in large independent cohorts, taking into account the method of treatment, gender, smoking, age, which also affect methylation patterns, and ethnical background further challenge identification of optimal methylation signature for detecting early stomach malignant events.

Ideally, good screening biomarkers should be associated with gastric cancer, regardless of $H$. pylori status (99), detectable in easily accessible body fluids, such as blood or urine, unrelated to the gender and age, and specific for detecting early stages of the disease $(35,100)$. Although several epimarkers, such as CDH1, CHFR, DAPK, GSTP1, MLH1, p15, p16, RUNX3, RAR $\beta, R A S S F 1 A$, and TFFPI2 have emerged as potential screening biomarkers that are detectable in serum or plasma of patients; none has yet reached a sufficiently high level of specificity and reliability for early detection of gastric cancer $(89,96)$.

\section{Conclusions}

The synthesis of available knowledge regarding DNA methylation markers relevant for cancers is extremely complex and here we attempted to depict the intricacy and heterogeneity of this field. Certainly, additional large mining studies could reveal novel and relevant biomarkers that could easily be overlooked in smaller literature reviews such as ours. Though aberrations of DNA methylation patterns appear to be relevant carcinogenic mechanisms, the translation of these findings into sensitive and specific diagnostic tests is hindered by the heterogeneity of epigenetic events in individuals and overlapping methylation changes that occur in different cancers $(28,32)$. Detection of global hypomethylation and focal hypermethylation patterns is technically demanding and currently not cost-effective for clinical laboratories. Even with modern accurate technologies available for detecting epimarkers in body fluids, the main disadvantage of these markers, namely specificity, still persists. Anti-profiling, looking for departure of methylation patterns from normal ones, is currently not applicable for the detection of the disease in whole blood (101).

One of the most promising aspects in this field is that despite complex and expensive technologies used for research, the output panels of biomarkers, specific for detecting methylation aberrations, could be interrogated with relatively simple PCRbisulphite methods, easily applicable to the most clinical laboratories. Moreover, several commercial enterprises are offering professional diagnostic services using advanced methods such as next generation sequencing etc. for the detection of common methylation aberrations. On the other hand, the interpretation of these results is often confusing and complicated, thus requiring establishment of multidisciplinary genetic counselling teams within healthcare institutions, which will be able to deliver meaningful explanations of the analyses.

The main headway in the cancer DNA methylation research would be to replicate the findings of aberrant methylation patterns present in tissues to more accessible diagnostic samples like stool, sputum, urine, blood or serum. However, clinically applicable methylation assays still await more replication studies, testing on large cohorts of patients and healthy controls, validations with different methods, and functional analyses of methylation patterns in order to determine, if the specific methylation patterns are exclusively associated with the disease or are by-products of immune response to tumour development, stress or treatments.

\section{Potential conflict of interest}

None declared. 


\section{References}

1. Inbar-Feigenberg $M$, Choufani S, Butcher DT, Roifman M, Weksberg R. Basic concepts of epigenetics. Fertil Steril 2013;99:607-15. http://dx.doi.org/10.1016/j.fertnstert. 2013.01.117.

2. Korkmaz A, Manchester L, Topal T, Shuran M, Tan D, Reiter R. Epigenetic mechanisms in human physiology and diseases. J Exp Integr Med 2011;1:139-47. http://dx.doi. org/10.5455/jeim.060611.rw.003.

3. Mazzio EA, Soliman KF. Basic concepts of epigenetics: impact of environmental signals on gene expression. Epigenetics 2012;7:119-30. http://dx.doi.org/10.4161/epi.7.2.18764.

4. Ellis L, Atadja PW, Johnstone RW. Epigenetics in cancer: targeting chromatin modifications. Mol Cancer Ther 2009; 8:1409-20. http://dx.doi.org/10.1158/1535-7163.MCT-08-0860.

5. Sandoval J, Esteller M. Cancer epigenomics: beyond genomics. Curr Opin Genet Dev 2012;22:50-5. http://dx.doi. org/10.1016/j.gde.2012.02.008.

6. Sandoval J, Peiro-Chova L, Pallardo FV, Garcia-Gimenez $J$ L. Epigenetic biomarkers in laboratory diagnostics: emerging approaches and opportunities. Expert Rev Mol Diagn 2013;13:457-71. http://dx.doi.org/10.1586/erm.13.37.

7. Handel AE, Ebers GC, Ramagopalan SV. Epigenetics: molecular mechanisms and implications for disease. Trends Mol Med 2010;16:7-16. http://dx.doi.org/10.1016/j.moImed.2009.11.003.

8. Jiménez-Chillarón JC, Díaz $R$, Martínez $D$, Pentinat $T$, Ramón-Krauel M, Ribó S, et al. The role of nutrition on epigenetic modifications and their implications on health. Biochimie 2012;94:2242-63. http://dx.doi.org/10.1016/j.biochi.2012.06.012.

9. Kang C, Song JJ, Lee J, Kim MY. Epigenetics: an emerging player in gastric cancer. World J Gastroenterol 2014;20:643347. http://dx.doi.org/10.3748/wjg.v20.i21.6433.

10. Heyn H, Moran S, Hernando-Herraez I, Sayols S, Gomez A, Sandoval J, et al. DNA methylation contributes to natural human variation. Genome Res 2013;23:1363-72. http:// dx.doi.org/10.1101/gr.154187.112.

11. Feinberg AP, Vogelstein B. Hypomethylation distinguishes genes of some human cancers from their normal counterparts. Nature 1983;301:89-92. http://dx.doi. org/10.1038/301089a0.

12. Lao VV, Grady WM. Epigenetics and colorectal cancer. Nat Rev Gastroenterol Hepatol 2011;8:686-700. http://dx.doi. org/10.1038/nrgastro.2011.173.

13. Kim JK, Samaranayake M, Pradhan S. Epigenetic mechanisms in mammals. Cell Mol Life Sci 2009;66:596-612. http:// dx.doi.org/10.1007/s00018-008-8432-4.

14. Doi $A$, Park IH, Wen B, Murakami P, Aryee $M J$, Irizarry $R$, et al. Differential methylation of tissue- and cancer-specific $C p G$ island shores distinguishes human induced pluripotent stem cells, embryonic stem cells and fibroblasts. Nat Genet 2009;41:1350-3. http://dx.doi.org/10.1038/ng.471.

15. Irizarry RA, Ladd-Acosta C, Wen B, Wu Z, Montano C, Onyango $P$, et al. The human colon cancer methylome shows similar hypo- and hypermethylation at conserved tissue-specific CpG island shores. Nat Genet 2009;41:178-86. http://dx.doi.org/10.1038/ng.298.
16. Mikeska T, Craig JM. DNA methylation biomarkers: cancer and beyond. Genes (Basel) 2014;5:821-64. http://dx.doi. org/10.3390/genes5030821.

17. Laird PW. Principles and challenges of genomewide DNA methylation analysis. Nat Rev Genet 2010;11:191-203. http://dx.doi.org/10.1038/nrg2732.

18. Han Y, Garcia BA. Combining genomic and proteomic approaches for epigenetics research. Epigenomics 2013;5:439-52. http://dx.doi.org/10.2217/epi.13.37.

19. Kalari S, Pfeifer GP. Identification of driver and passenger DNA methylation in cancer by epigenomic analysis. Adv Genet 2010;70:277-308. http://dx.doi.org/10.1016/B978-012-380866-0.60010-1.

20. Holmes EE, Jung M, Meller S, Leisse A, Sailer V, Zech J, et al. Performance evaluation of kits for bisulfite-conversion of DNA from tissues, cell lines, FFPE tissues, aspirates, lavages, effusions, plasma, serum, and urine. PLoS ONE 2014;9:e93933. http://dx.doi.org/10.1371/journal. pone.0093933.

21. Mikeska T, Bock C, Do H, Dobrovic A. DNA methylation biomarkers in cancer: progress towards clinical implementation. Expert Rev Mol Diagn 2012;12:473-87. http://dx.doi. org/10.1586/erm.12.45.

22. Mikeska T, Felsberg J, Hewitt CA, Dobrovic A. Epigenetics Protocols. Epigenetics Protocols 2011;791:33-53. http:// dx.doi.org/10.1007/978-1-61779-316-5_4.

23. Kristensen LS, Hansen LL. PCR-based methods for detecting single-locus DNA methylation biomarkers in cancer diagnostics, prognostics, and response to treatment. Clin Chem 2009;55:1471-83. http://dx.doi.org/10.1373/ clinchem.2008.121962

24. Wojdacz TK. Methylation-sensitive high-resolution melting in the context of legislative requirements for validation of analytical procedures for diagnostic applications. Expert Rev Mol Diagn 2012;12:39-47. http://dx.doi.org/10.1586/ erm.11.88.

25. Xiao Z, Li B, Wang G, Zhu W, Wang Z, Lin J, et al. Validation of methylation-sensitive high-resolution melting (MSHRM) for the detection of stool DNA methylation in colorectal neoplasms. Clin Chim Acta 2014;431:154-63. http:// dx.doi.org/10.1016/j.cca.2014.01.044.

26. Kristensen LS, Wojdacz TK, Thestrup BB, Wiuf $C$, Hager $H$, Hansen LL. Quality assessment of DNA derived from up to 30 years old formalin fixed paraffin embedded (FFPE) tissue for PCR-based methylation analysis using SMARTMSP and MS-HRM. BMC cancer 2009;9:453. http://dx.doi. org/10.1186/1471-2407-9-453.

27. Coolen MW, Statham AL, Gardiner-Garden M, Clark SJ. Genomic profiling of $C p G$ methylation and allelic specificity using quantitative high-throughput mass spectrometry: critical evaluation and improvements. Nucleic Acids Res 2007;35:e119. http://dx.doi.org/10.1093/nar/gkm662.

28. Garcia-Gimenez JL, Sanchis-Gomar F, Lippi G, Mena S, Ivars $D$, Gomez-Cabrera $M C$, et al. Epigenetic biomarkers: A new perspective in laboratory diagnostics. Clin Chim Acta 2012;413:1576-82. http://dx.doi.org/10.1016/j. cca.2012.05.021. 
29. Taylor KH, Kramer RS, Davis JW, Guo J, Duff DJ, Xu $D_{1}$ et al. Ultradeep bisulfite sequencing analysis of DNA methylation patterns in multiple gene promoters by 454 sequencing. Cancer Res 2007;67:8511-8. http://dx.doi. org/10.1158/0008-5472.CAN-07-1016.

30. Sandoval J, Heyn H, Moran S, Serra-Musach J, Pujana MA, Bibikova $M$, et al. Validation of a DNA methylation microarray for $450,000 \mathrm{CpG}$ sites in the human genome. Epigenetics 2014;6:692-702. http://dx.doi.org/10.4161/ epi.6.6.16196.

31. Jasmine F, Rahaman $R$, Roy $S$, Raza M, Paul R, RakibuzZaman $M$, et al. Interpretation of genome-wide infinium methylation data from ligated DNA in formalin-fixed, paraffin-embedded paired tumor and normal tissue. BMC Res Notes 2012;5:117. http://dx.doi.org/10.1186/1756-0500-5117.

32. Heichman KA, Warren JD. DNA methylation biomarkers and their utility for solid cancer diagnostics. Clin Chem Lab Med 2012;50:1707-21. http://dx.doi.org/10.1515/cclm2011-0935.

33. Li L, Choi JY, Lee KM, Sung H, Park SK, Oze I, et al. DNA methylation in peripheral blood: a potential biomarker for cancer molecular epidemiology. J Epidemiol 2012;22:38494. http://dx.doi.org/10.2188/jea.JE20120003.

34. Timp W, Feinberg AP. Cancer as a dysregulated epigenome allowing cellular growth advantage at the expense of the host. Nat Rev Cancer 2013;13:497-510. http://dx.doi. org/10.1038/nrc3486.

35. Ma Y, Wang $X$, Jin $H$. Methylated DNA and microRNA in Body Fluids as Biomarkers for Cancer Detection. Int J Mol Sci 2013;14:10307-31. http://dx.doi.org/10.3390/ ijms140510307.

36. Kanwal Gupta S, R. Epigenetic modifications in cancer. Clin Genet 2013;81:303-11. http://dx.doi.org/10.1111/j.13990004.2011.01809.x.

37. How Kit A, Nielsen HM, Tost J. DNA methylation based biomarkers: practical considerations and applications. Biochimie 2012;94:2314-37. http://dx.doi.org/10.1016/j.biochi.2012.07.014.

38. Li J, Huang Q, Zeng F, Li W, He Z, Chen W, et al. The prognostic value of global DNA hypomethylation in cancer: a meta-analysis. PLOS ONE 2014;9:e106290. http://dx.doi. org/10.1371/journal.pone.0106290.

39. Stefansson OA, Moran S, Gomez A, Sayols S, Arribas-Jorba $C$, Sandoval J, et al. A DNA methylation-based definition of biologically distinct breast cancer subtypes. Mol Oncol 2015;9:555-68.http://dx.doi.org/10.1016/j.molonc.2014.10.012.

40. Etzioni R, Urban N, Ramsey S, McIntosh M, Schwartz S, Reid $B$, et al. The case for early detection. Nature Reviews Cancer 2003;3:243-52.http://dx.doi.org/10.1038/nrc1041.

41. Wong EM, Southey MC, Fox SB, Brown MA, Dowty JG, Jenkins $M A$, et al. Constitutional methylation of the BRCA1 promoter is specifically associated with BRCA1 mutationassociated pathology in early-onset breast cancer. Cancer Prev Res 2011;4:23-33. http://dx.doi.org/10.1158/19406207.CAPR-10-0212.
42. Cai F, Ge I, Wang M, Biskup E, Lin X, Zhong X. Pyrosequencing analysis of BRCA1 methylation level in breast cancer cells. Tumour Biol 2014;35:3839-44. http://dx.doi. org/10.1007/s13277-013-1508-2.

43. Fackler MJ, Lopez Bujanda Z, Umbricht C, Teo WW, Cho $S$, Zhang $Z$, et al. Novel methylated biomarkers and a robust assay to detect circulating tumor DNA in metastatic breast cancer. Cancer Res 2014;74:2160-70. http://dx.doi. org/10.1158/0008-5472.CAN-13-3392.

44. Kloten V, Becker B, Winner $K$, Schrauder MG, Fasching PA, Anzeneder $T$, et al. Promoter hypermethylation of the tumor-suppressor genes ITIH5, DKK3, and RASSF1A as novel biomarkers for blood-based breast cancer screening. Breast Cancer Res 2013;15:R4. http://dx.doi.org/10.1186/ bcr3375.

45. Radpour R, Kohler C, Haghighi MM, Fan AX, Holzgreve $W$, Zhong XY. Methylation profiles of 22 candidate genes in breast cancer using high-throughput MALDI-TOF mass array. Oncogene 2009;28:2969-78.http://dx.doi. org/10.1038/onc.2009.149.

46. Radpour R, Barekati Z, Kohler C, Lv Q, Burki N, Diesch C, et al. Hypermethylation of tumor suppressor genes involved in critical regulatory pathways for developing a blood-based test in breast cancer. PLOS ONE 2011;6:e16080. http:// dx.doi.org/10.1371/journal.pone.0016080.

47. Agostini M, Enzo MV, Bedin C, Belardinelli V, Goldin E, Del Bianco $P$, et al. Circulating cell-free DNA: a promising marker of regional lymphonode metastasis in breast cancer patients. Cancer Biomark 2012;11:89-98.

48. Fleischer T, Edvardsen H, Solvang HK, Daviaud C, Naume B, Borresen-Dale $A L$, et al. Integrated analysis of high-resolution DNA methylation profiles, gene expression, germline genotypes and clinical end points in breast cancer patients. Int J Cancer 2014;134:2615-25. http://dx.doi.org/10.1002/ ijc.28606.

49. Hinton J, Callan R, Bodine C, Glasgow W, Brower S, Jiang SW, et al. Potential epigenetic biomarkers for the diagnosis and prognosis of pancreatic ductal adenocarcinomas. Expert Rev Mol Diagn 2013;13:431-43. http://dx.doi. org/10.1586/erm.13.38.

50. Huang Z, Liu F. Diagnostic value of serum carbohydrate antigen 19-9 in pancreatic cancer: a meta-analysis. Tumour Biol 2014;35:7459-65. http://dx.doi.org/10.1007/s13277014-1995-9.

51. McCleary-Wheeler AL, Lomberk GA, Weiss FU, Schneider $G$, Fabbri M, Poshusta $T L$, et al. Insights into the epigenetic mechanisms controlling pancreatic carcinogenesis. Cancer Lett 2013;328:212-21. http://dx.doi.org/10.1016/j.canlet.2012.10.005.

52. Fukushige S, Horii A. Road to early detection of pancreatic cancer: Attempts to utilize epigenetic biomarkers. Cancer Lett 2014;342:231-7. http://dx.doi.org/10.1016/j.canlet.2012.03.022.

53. Neureiter D, Jager T, Ocker M, Kiesslich T. Epigenetics and pancreatic cancer: pathophysiology and novel treatment aspects. World J Gastroenterol 2014;20:7830-48. http:// dx.doi.org/10.3748/wjg.v20.i24.7830. 
54. Nagpal G, Sharma M, Kumar S, Chaudhary K, Gupta S, Gautam $A$, et al. PCMdb: pancreatic cancer methylation database. Sci Rep 2014;4:4197. http://dx.doi.org/10.1038/ srep04197.

55. Yi JM, Guzzetta AA, Bailey VJ, Downing SR, Van Neste L, Chiappinelli $K B$, et al. Novel methylation biomarker panel for the early detection of pancreatic cancer. Clin Cancer Res 2013;19:6544-55. http://dx.doi.org/10.1158/1078-0432.CCR12-3224.

56. Sato $N$, Fukushima $N$, Maitra A, Matsubayashi $H$, Yeo CJ, Cameron $\mathrm{J}$ et al. Discovery of novel targets for aberrant methylation in pancreatic carcinoma using high-throughput microarrays. Cancer Res 2003;63:3735-42.

57. Park JK, Ryu JK, Yoon WJ, Lee SH, Lee GY, Jeong KS, et al. The role of quantitative NPTX2 hypermethylation as a novel serum diagnostic marker in pancreatic cancer. Pancreas 2012;41:95101. http://dx.doi.org/10.1097/MPA.0b013e318221c903.

58. Pedersen KS, Bamlet WR, Oberg AL, de Andrade M, Matsumoto $M E$, Tang $H$, et al. Leukocyte DNA methylation signature differentiates pancreatic cancer patients from healthy controls. PLOS ONE 2011;6:e18223. http://dx.doi. org/10.1371/journal.pone.0018223.

59. Dauksa A, Gulbinas A, Barauskas G, Pundzius J, Oldenburg J, El-Maarri O. Whole blood DNA aberrant methylation in pancreatic adenocarcinoma shows association with the course of the disease: a pilot study. PLoS ONE 2012;7:e37509. http://dx.doi.org/10.1371/journal.pone.0037509.

60. Esplin ED, Snyder MP. Genomic era diagnosis and management of hereditary and sporadic colon cancer. World J Clin Oncol 2014;5:1036-47. http://dx.doi.org/10.5306/wjco. v5.i5.1036.

61. Mitchell SM, Ross JP, Drew HR, Ho T, Brown GS, Saunders $N F$, et al. A panel of genes methylated with high frequency in colorectal cancer. BMC cancer 2014;14:54. http://dx.doi. org/10.1186/1471-2407-14-54.

62. Lange $C P$, Campan $M$, Hinoue $T$, Schmitz RF, van der Meulen-de Jong $A E$, Slingerland $H$, et al. Genome-scale discovery of DNA-methylation biomarkers for blood-based detection of colorectal cancer. PLOS ONE 2012;7:e50266. http://dx.doi.org/10.1371/journal.pone.0050266.

63. Antelo M, Balaguer F, Shia J, Shen Y, Hur K, Moreira L, et al. A high degree of LINE-1 hypomethylation is a unique feature of early-onset colorectal cancer. PLOS ONE 2012;7:e45357. http://dx.doi.org/10.1371/journal.pone.0045357.

64. Naito T, Nosho K, Ito M, Igarashi H, Mitsuhashi K, Yoshii S, et al. IGF2 differentially methylated region hypomethylation in relation to pathological and molecular features of serrated lesions. World J Gastroenterol 2014;20:10050-61. http://dx.doi.org/10.3748/wjg.v20.i29.10050.

65. Hansen KD, Timp W, Bravo HC, Sabunciyan S, Langmead $B, M c D o n a l d ~ O G$, et al. Increased methylation variation in epigenetic domains across cancer types. Nat Genet 2011;43:768-75. http://dx.doi.org/10.1038/ng.865.

66. Berman BP, Weisenberger DJ, Aman JF, Hinoue T, Ramjan $Z$, Liu Y, et al. Regions of focal DNA hypermethylation and long-range hypomethylation in colorectal cancer coincide with nuclear lamina-associated domains. Nat Genet 2012;44:40-6. http://dx.doi.org/10.1038/ng.969.
67. Zullo JM, Demarco IA, Pique-Regi R, Gaffney DJ, Epstein $C B_{1}$ Spooner $C J$, et al. DNA sequence-dependent compartmentalization and silencing of chromatin at the nuclear la mina. Cell 2012;149:1474-87. http://dx.doi.org/10.1016/j. cell.2012.04.035.

68. Arnold S, Buchanan DD, Barker M, Jaskowski L, Walsh MD, Birney $G$, et al. Classifying MLH1 and MSH2 variants using bioinformatic prediction, splicing assays, segregation, and tumor characteristics. Hum Mutat 2009;30:757-70. http:// dx.doi.org/10.1002/humu.20936.

69. Petersen SM, Dandanell M, Rasmussen LJ, Gerdes AM, Krogh $L N$, Bernstein I, et al. Functional examination of MLH1, MSH2, and MSH6 intronic mutations identified in Danish colorectal cancer patients. BMC Med Genet 2013;14:103. http://dx.doi.org/10.1186/1471-2350-14-103.

70. Vogelsang $M$, Comino A, Zupanec $N$, Hudler $P$, Komel $R$. Assessing pathogenicity of $\mathrm{MLH1}$ variants by co-expression of human MLH1 and PMS2 genes in yeast. BMC cancer 2009;9:382. http://dx.doi.org/10.1186/1471-2407-9-382.

71. de Vogel $S$, Weijenberg MP, Herman JG, Wouters $K A$, de Goeij AF, van den Brandt PA, et al. MGMT and MLH1 promoter methylation versus $A P C, K R A S$ and $B R A F$ gene mutations in colorectal cancer: indications for distinct pathways and sequence of events. Ann Oncol 2009;20:1216-22. http://dx.doi.org/10.1093/annonc/mdn782.

72. Hawkins NJ, Lee JH, Wong JJ, Kwok CT, Ward RL, Hitchins MP. MGMT methylation is associated primarily with the germline C>T SNP (rs16906252) in colorectal cancer and normal colonic mucosa. Mod Pathol 2009;22:1588-99. http://dx.doi.org/10.1038/modpathol.2009.130.

73. Shima K, Morikawa T, Baba Y, Nosho K, Suzuki M, Yamauchi $M$, et al. MGMT promoter methylation, loss of expression and prognosis in 855 colorectal cancers. Cancer Causes Control 2011;22:301-9. http://dx.doi.org/10.1007/s10552-010-9698-z.

74. He Q, Chen HY, Bai EQ, Luo YX, Fu RJ, He YS, et al. Development of a multiplex MethyLight assay for the detection of multigene methylation in human colorectal cancer. Cancer Genet Cytogenet 2010;202:1-10. http://dx.doi. org/10.1016/j.cancergencyto.2010.05.018.

75. Weisenberger DJ, Campan M, Long TI, Laird PW. Determination of the CpG Island Methylator Phenotype (CIMP) in colorectal cancer using MethyLight. Protocol Exchange 2006. http://dx.doi.org/10.1038/nprot.2006.152.

76. deVos T, Tetzner R, Model F, Weiss G, Schuster M, Distler J, et al. Circulating methylated SEPT9 DNA in plasma is a biomarker for colorectal cancer. Clin Chem 2009;55:1337-46. http://dx.doi.org/10.1373/clinchem.2008.115808.

77. Ned RM, Melillo S, and Marrone M. Fecal DNA testing for Colorectal Cancer Screening: the ColoSure test. PLoS Curr 2011;3:RRN1220. http://dx.doi.org/10.1371/currents.RRN1220.

78. Shirahata A, Sakuraba K, Goto T, Saito M, Ishibashi $K, K i$ gawa $G$ et al. Detection of vimentin (VIM) methylation in the serum of colorectal cancer patients. Anticancer Res 2010;30:5015-8.

79. Ladabaum U, Allen J, Wandell M, Ramsey S. Colorectal cancer screening with blood-based biomarkers: cost-effectiveness of methylated septin 9 DNA versus current strategies. Cancer Epidemiol Biomarkers Prev 2013;22:1567-76. http:// dx.doi.org/10.1158/1055-9965.EPI-13-0204. 
80. Payne SR. From discovery to the clinic: the novel DNA methylation biomarker ( $m$ )SEPT9 for the detection of colorectal cancer in blood. Epigenomics 2010;2:575-85. http:// dx.doi.org/10.2217/epi.10.35.

81. Warren $J D$, Xiong $W$, Bunker $A M$, Vaughn $C P$, Furtado $L V$, Roberts $W L$, et al. Septin 9 methylated DNA is a sensitive and specific blood test for colorectal cancer. BMC Med 2011;9:133. http://dx.doi.org/10.1186/1741-7015-9-133.

82. de Martel C, Forman D, Plummer M. Gastric cancer: epidemiology and risk factors. Gastroenterol Clin North Am 2013;42:219-40. http://dx.doi.org/10.1016/j. gtc.2013.01.003.

83. Hudler P. Genetic aspects of gastric cancer instability. ScientificWorldJournal 2012;2012:761909. http://dx.doi. org/10.1100/2012/761909.

84. Hudler P, Kocevar N, Komel R. Proteomic approaches in biomarker discovery: new perspectives in cancer diagnostics. ScientificWorldJournal 2014;2014:260348. http://dx.doi. org/10.1155/2014/260348.

85. Pinheiro Ddo R, Ferreira WA, Barros MB, Araujo MD, Rodrigues-Antunes $S$, Borges Bdo N. Perspectives on new biomarkers in gastric cancer: diagnostic and prognostic applications. World J Gastroenterol 2014;20:11574-85. http:// dx.doi.org/10.3748/wjg.v20.i33.11574.

86. Alvarez MC, Santos JC, Maniezzo N, Ladeira MS, da Silva $A L$, Scaletsky IC, et al. MGMT and MLH1 methylation in Helicobacter pylori-infected children and adults. World J Gastroenterol 2013;19:3043-51. http://dx.doi.org/10.3748/ wjg.v19.i20.3043.

87. Hong SJ, Oh JH, Jeon EJ, Min KO, Kang MI, Choi SW, et al. The overmethylated genes in Helicobacter pylori-infected gastric mucosa are demethylated in gastric cancers. BMC Gastroenterol 2010;10:137. http://dx.doi.org/10.1186/1471230X-10-137.

88. LiuX, Chu KM. E-cadherin and gastric cancer: cause, consequence, and applications. Biomed Res Int 2014;2014:637308. http://dx.doi.org/10.1155/2014/637308.

89. Qu Y, Dang $S$, Hou P. Gene methylation in gastric cancer. Clin Chim Acta 2013;424:53-65. http://dx.doi.org/10.1016/j. cca.2013.05.002.

90. Zulfiqar M, Bhalla A, Weindel M, Shidham VB. Molecular diagnostics in esophageal and gastric neoplasms. Clin Lab Med 2013;33:867-73. http://dx.doi.org/10.1016/j. cll.2013.08.006.

91. Yuasa Y, Nagasaki H, Akiyama Y, Hashimoto Y, Takizawa T, Kojima $K$, et al. DNA methylation status is inversely correlated with green tea intake and physical activity in gastric cancer patients. Int J Cancer 2009;124:2677-82. http:// dx.doi.org/10.1002/ijc.24231.
92. Balassiano K, Lima S, Jenab $M$, Overvad $K$, Tjonneland $A$, Boutron-Ruault MC, et al. Aberrant DNA methylation of cancer-associated genes in gastric cancer in the European Prospective Investigation into Cancer and Nutrition (EPIC-EURGAST). Cancer Lett 2011;311:85-95. http://dx.doi. org/10.1016/j.canlet.2011.06.038.

93. Cheng Y, Yan Z, Liu Y, Liang C, Xia H, Feng J et al. Analysis of DNA methylation patterns associated with the gastric cancer genome. Oncol Lett 2014;7:1021-26.

94. Jiang L, Gonda TA, Gamble MV, Salas M, Seshan V, Tu S, et al. Global hypomethylation of genomic DNA in cancerassociated myofibroblasts. Cancer Res 2008;68:9900-8. http://dx.doi.org/10.1158/0008-5472.CAN-08-1319.

95. Loh M, Liem N, Vaithilingam A, Lim PL, Sapari NS, Elahi $E$, et al. DNA methylation subgroups and the CpG island methylator phenotype in gastric cancer: a comprehensive profiling approach. BMC Gastroenterol 2014;14:55. http:// dx.doi.org/10.1186/1471-230X-14-55.

96. Sapari NS, Loh M, Vaithilingam A, Soong R. Clinical potential of DNA methylation in gastric cancer: a meta-analysis. PLOS ONE 2012;7:e36275. http://dx.doi.org/10.1371/journal.pone.0036275.

97. Nakamura J, Tanaka T, Kitajima Y, Noshiro H, Miyazaki K. Methylation-mediated gene silencing as biomarkers of gastric cancer: a review. World J Gastroenterol 2014;20:119912006. http://dx.doi.org/10.3748/wjg.v20.i34.11991.

98. Zong L, Seto Y. CpG island methylator phenotype, Helicobacter pylori, Epstein-Barr virus, and microsatellite instability and prognosis in gastric cancer: a systematic review and meta-analysis. PLoS ONE 2014;9:e86097. http://dx.doi. org/10.1371/journal.pone.0086097.

99. Shin CM, Kim N, Park JH, Kang GH, Kim JS, Jung HC, et al. Prediction of the risk for gastric cancer using candidate methylation markers in the non-neoplastic gastric mucosae. J Pathol 2012;226:654-65. http://dx.doi. org/10.1002/path.2990.

100. He CZ, Zhang KH.Serum Protein and Genetic Tumor Markers of Gastric Carcinoma. Asian Pacific J Cancer Prev 2013;14:3437-42. http://dx.doi.org/10.7314/APJCP.2013. 14.6.3437.

101. Teschendorff $A E$, Widschwendter M. Differential variability improves the identification of cancer risk markers in DNA methylation studies profiling precursor cancer lesions. Bioinformatics 2012;28:1487-94. http://dx.doi.org/10.1093/bioinformatics/bts 170 . 